\title{
Integrating the palynostratigraphy, petrography, X-ray diffraction and scanning electron microscopy data for evaluating hydrocarbon reservoir potential of Jurassic rocks in the Kala Chitta Range, Northwest Pakistan
}

\author{
Sajjad Ahmad ${ }^{1}$ D $\cdot$ Bilal Wadood $^{2,3}$ (D) $\cdot$ Suleman Khan $^{1}$ (D) $\cdot$ Sohail Ahmed $^{1} \cdot$ Fahad Ali $^{4}$ (D) Abdus Saboor $^{1}$ (D)
}

Received: 2 April 2020 / Accepted: 11 July 2020 / Published online: 18 July 2020

(C) The Author(s) 2020

\begin{abstract}
In this paper, we present the palynostratigraphy, petrography, scanning electron microscopy (SEM) and X-ray diffraction (XRD) investigations to evaluate hydrocarbon reservoir potential of the Jurassic clastic-carbonate mixed sequence of the Kala Chitta Range, northwest Pakistan. The chronostratigraphic sub-divisions of the diverse lithologies within the sequence were made by using palynostratigraphy. The clastic dominated sequence of Datta Formation was assigned Toarcian-Bajocian age, while the Shinawari Formation was deposited during the Bajocian-middle Bathonian. The carbonate shoal facies of the Samana Suk Formation showed late Bathonian-Tithonian time of deposition. The primary and secondary porosities augmented by the plug porosity and permeability data suggest that the sandstone of Datta Formation is an excellent reservoir. The dominance of diverse matrix within the Shinawari Formation occluded the primary porosity. However, based on dissolution and dolomitization, the Shinawari Formation is categorized as a moderate reservoir. The dominance of various types of matrix and cement with superimposed burial diagenesis has occluded the primary porosity within the Samana Suk Formation. However, the diagenetic dissolution and dolomitization during the telogenetic stage were supported by the SEM and bulk geochemical data. Such diagenetic overprinting has significantly enhanced the reservoir potential of the unit.
\end{abstract}

Keywords Jurassic · Palynostratigraphy · Reservoir · Porosity

Sajjad Ahmad

dr.s_ahmed@uop.edu.pk

Bilal Wadood

bilalwadood@uoswabi.edu.pk

Suleman Khan

sulemanafridi@uop.edu.pk

Fahad Ali

fahadalizai635@gmail.com

Abdus Saboor

abdus.saboor@uop.edu.pk

1 Department of Geology, University of Peshawar, Peshawar 25120, Pakistan

2 State Key Laboratory of Continental Dynamics, Department of Geology, Northwest University, Xi' an 710069, China

3 Department of Geology, University of Swabi, Anbar-Swabi 23561, Pakistan

4 Department of Geology, Bacha Khan University, Charsadda 24420, Pakistan

\section{Introduction}

Pakistan has over 9 billion barrels of petroleum oil and 105 trillion cubic feet (TCF) natural gas (including shale gas) reserves (according to the data of United States Energy Information Administration EIA 2013). The recoverable oil reserves stand at approximately 340 million barrels, and the gas reserves are 20 TCF (MPCL 2020). The prevailing energy crises in Pakistan calls for immediate attention to device novel strategies for the exploration and exploitation of the hidden and existing hydrocarbon resources and to assess the contribution of novel strategies for Pakistan's energy endowment in the future.

The current study aims to investigate the hydrocarbon reservoirs in the unexplored Kala Chitta Range in northwest Pakistan. The Kala Chitta Range is an east-west trending intensely deformed mountainous belt which merges laterally into the Hazara Mountains in the east and the Kohat and Samana ranges in the west (Yeats and Hussain 1987). It is 
bounded to the north by the Hissartang Thrust Fault, while the Main Boundary Thrust (MBT) lies in its south (Yeats and Hussain 1987; Fig. 1). The exposed sedimentary succession of the study area ranges in age from the Jurassic-Miocene, which includes the Datta, Shinawari, Samana Suk, Chichali, Lumshiwal, Kawagarh, Lockhart, Patala, Margalla Hills, and Murree formations (Shah 2009; Fig. 1). The study area is a lateral stratigraphic continuation of the petroliferous strata of the Kohat and Potwar basins in the west (Kadri 1995). A viable unexplored petroleum system is expected in the Kala Chitta Range. The Jurassic units of Kala Chitta Range include Datta, Shinawari and Samana Suk formations (Shah 2009). These units have diverse lithologies ranging from deltaic dominated sandstone/shales to shallow-marine carbonates (Iqbal et al. 2015; Ali et al. 2019; Wadood et al. 2020). Such diverse variation in lithology of Datta Formation can host various hydrocarbon source rock intervals, reservoir compartments and cap rocks (Kadri 1995). The organicrich black shales in the lower part of the Datta Formation was deposited in the dysoxic to anoxic water setting, which may act as a potential source rock for the sandstone unit within the Datta Formation (Kadri 1995). Previously, the source rock potential of the Datta Formation is established in the adjacent Potwar Basin in the west (Kadri 1995). The Datta Formation is also a proven oil-producing reservoir in the Chanda, Dhulian, Mial and Toot oil fields in Banu, Kohat, and Punjab platform of the Upper Indus Basin (Kadri 1995; Khan and Rehman 2019). The organic-rich shales in the upper part of the Datta Formation and lower part of the Shinawari Formation can be a seal for the sandy reservoir intervals of the Datta Formation. The same shale interval may have acted as a potential source for the Shinawari and

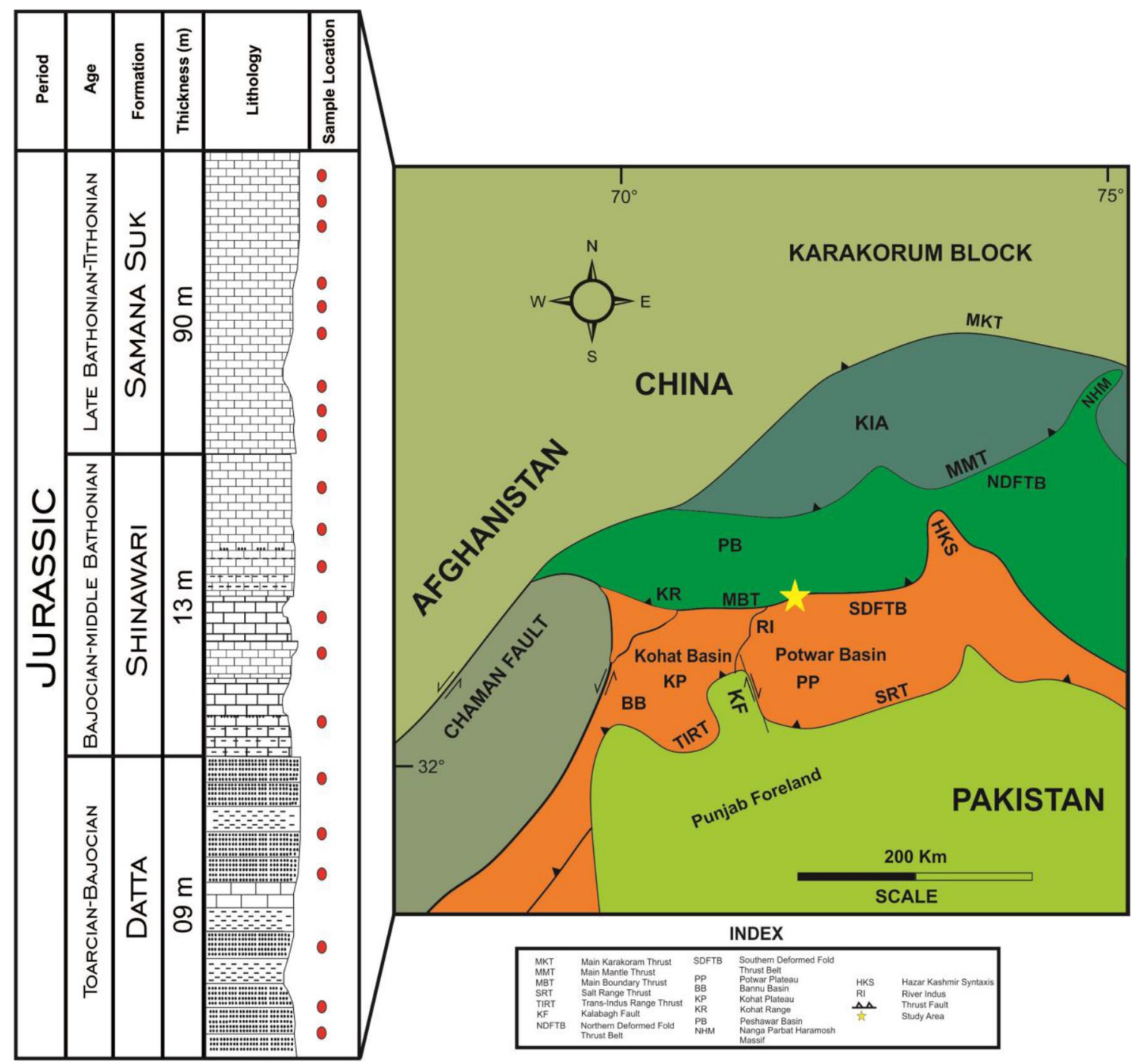

Fig. 1 Tectonic map of Pakistan (modified after Banks and Warburton 1986; Kazmi and Rana 1982) and lithological log of the Datta, Shinawari and Samana Suk formations in the study area at the left side 
Samana Suk formations (see, e.g., Shah and Ahmed 2018). The Shinawari and Samana Suk formations are producing oil reservoirs in the Dhulian, Mial, and Toot oil fields (Kadri 1995). The glauconitic siltstone/shale in the lower part of the Early Cretaceous Chichali Formation can be a good seal for the carbonate intervals of the Shinawari and Samana Suk formations (Kadri 1995). The Jurassic units (Datta, Shinawari and Samana Suk formations) were previously evaluated by various researchers in the context of sedimentology, sequence stratigraphy, diagenesis and reservoir evaluation in different ranges and sections in the Upper Indus Basin (e.g., Ahmed et al. 1997; Ali et al. 2013; Bender and Raza 1995; Cheema 2010; Fatmi et al. 1990; Hallam and Maynard 1987; Latif 1970; Mertmann and Ahmad 1994; Nizami and Shiekh 2009; Nizami 2009; Qureshi et al. 2008; Shah 2009; Wadood et al. 2020). However, no integrated studies have been carried out for a viable chronostratigraphic calibration and evaluation of the hydrocarbon reservoir potential of Jurassic strata in the study area.

Worldwide, the initial exploration of oil and gas was based on the conventional methods (i.e., regional tectonics, structure and stratigraphic evaluation). At present, the excessive exploration activities demand careful assessment of reservoir using more advanced techniques such as the petrographic, geochemical and SEM analyses which are widely used to study the evolution of porosity and impacts of diagenesis on the overall reservoir potential of a rock unit (Ali et al. 2010). Similarly, the porosity-permeability analysis determines pore throats size, geometric arrangement and interconnection of pores which may help in the productivity and efficient recovery of hydrocarbons from a reservoir (Jodry 1972; Bliefnick and Kaldi 1996; Wardlaw and Cassan 1978; Kopaska-Merkel et al. 1994). The identification of typical minerals and cement types by using the $\mathrm{X}$-ray diffraction analysis greatly affects the porosity-permeability of hydrocarbon reservoirs. The clay minerals such as smectites, bentonites and montmorillonites swell as it mixes with freshwater and thus causes blockage for the fluid flow within the pore spaces (Wilson et al. 2014). The primary (matrix) and secondary permeability originate during deposition and diagenesis, respectively (Selley and Sonnenberg 2014). The diagenetic alteration also reduces the permeability by cementation and compaction (Evans 1987). The dominance of platy minerals, e.g., muscovite and laminated shale hinders the vertical flow of hydrocarbons (Potter et al. 2012). Therefore, comprehending the clay mineralogy, their abundance, distribution as well as the composition of the pore fluids is obviously important. The clay minerals coating the grain surfaces either expand or dislodged as a result of a change in the chemistry of the pore fluids and mud filtrate consequently reducing the permeability of a reservoir (Potter et al. 2012). The porosity and permeability of the strata can be affected by the extent and location of cementation within the pore space. Furthermore, the percolating mineral solutions of low $\mathrm{PH}$ within the carbonate rocks along with the primary pores, fissures, fractures and bedding planes enhances the effective porosity of the reservoirs. Such kind of diagenetic changes in clastic and carbonate intervals can be better elucidated with integrated studies.

The integration of petrography with advance microscopic and geochemical techniques including XRD and SEM analyses unravel the evolution of nano-porosity, cement stratigraphy, and hydrodynamic history of the sedimentary basins. It also helps in the clear understanding of hydrocarbon maturation, migration, and destruction history (i.e., Foscolos 1984; Burruss et al. 1985; Moore and Druckman 1981; Surdam et al. 1984, 1989; Crossey et al. 1986; Edman and Surdam 1986; Hutcheon et al. 1989; Spirakis and Heyl 1988; Mazzullo and Harris 1989). Therefore, in the current study, we used the pollen and spores data for establishing a sound and reliable palynostratigraphic framework, detailed petrography focusing on the diagenetic fabric, cement, and porosity types, X-ray diffraction analysis (XRD) for confirming the type of minerals, scanning electron microscopy (SEM) for the evaluation of nano-porosity, and plug porosity/permeability analysis for the direct measurement of porosity/ permeability of the Jurassic strata in the Kala Chitta Range, northwest Pakistan. It is expected that we may use these techniques as a valuable tool for the hydrocarbon reservoir characterization at various stages of exploration, appraisal, and development studies in the region.

\section{Materials and methods}

The geological fieldwork was carried out in the Kala Chitta Range (Fig. 1), and random rock samples were collected from the Datta, Shinawari, and Samana Suk formations for various laboratory analyses at the Department of Geology, University of Peshawar, Pakistan. Standard petrographic thin-sections were made. For the palynostratigraphy, $200 \mathrm{~g}$ clay samples were first grinded to $2 \mathrm{~mm}$ size particles. The grinded samples were put in the glass beaker, and $10 \%$ hydrochloric $(\mathrm{HCl})$ acid was added to remove the carbonate fraction. The supernatants were sieved through a 10-micron nylon sieve. The leftover residue was added to a Teflon beaker, and $60 \%$ hydrofluoric (HF) acid was added to remove the silicate fraction. The samples were retained in HF overnight. The supernatants were sieved again through a 10-micron nylon sieve. The water was removed through pipette from the organic residue, and the residue was put on glass slides for the petrographic studies. A drop of water was added for the better visibility and photomicrography of the organic microfossils. The diagenetic features were systematically recorded to unravel its effects on the porosity and permeability. The SEM images and XRD analysis were

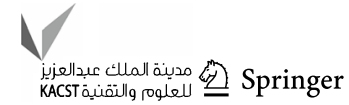


performed in the Centralized Resource Laboratory, University of Peshawar, Pakistan. The plug porosity and permeability analyses of the samples were carried out at the Hydrocarbon Development Institute of Pakistan. The core plugs of about $2.54 \mathrm{~cm}$ were placed in porosimeter and permometer for analyses. The data were automatically acquired and displayed in real-time and stored in user-selectable directories without any operator intervention. The porosity/permeability data acquired through plug testing were used to understand the relationship between porosity and permeability by constructing cross-plots following Wadood et al. (2020).

\section{Results}

\section{Palynostratigraphic framework}

The Jurassic outcrops have stratigraphic similarities with the Cretaceous-Paleocene strata in the Kala Chitta Range. Lack of the Jurassic bio-palynostratigraphic framework hinders the accurate stratigraphic identification and correlation. Therefore, pollen and spore data from the clastic-carbonate mixed lithologies of the Jurassic rocks of the study area were used to construct an accurate and viable chronostratigraphic framework. The palynostratigraphic calibration greatly influences the reservoir fingerprinting, the stratigraphic correlation at surface and subsurface, unconformity, seal and trap demarcation and appraisal in various stages of hydrocarbon exploration and development studies. The combination of various lithological attributes and floral elements were used to assign relative ages to the uncertain stratigraphic units.

\section{Datta Formation}

The Datta Formation mostly consists of mixed sandstone, siltstone, carbonaceous iron-rich clays, and coal seams at places (Abbasi et al. 2012). In the study area, the rock unit is overlain disconformably by the Triassic Kingriali Formation and underlain conformably by the Samana Suk Formation. Based on the occurrence of age diagnostic pollen and spores Callialasporites turbatus assemblage biozone is defined. This biozone contains Callialasporites diamperi and Callialasporites turbatus which confirms a Toarcian-Bajocian age of the Datta Formation (Fig. 2).

\section{Shinawari Formation}

The name Shinawari Formation was introduced by Fatmi (1973) for the transition zone between the Datta and overlying Samana Suk Formation of the Surghar Group in the western Samana Range. The Shinawari Formation is dominated by mixed limestone, sandstone, shale, marls, siltstone, and mudstone units with the association of laterite, hardgrounds, and coal layers. The pollen and spores record of the unit marks the Callialasporites trilobatus assemblage biozone which confirms the Bajocian-middle Bathonian age of the Shinawari Formation (Fig. 2).

\section{Samana Suk Formation}

The Samana Suk Formation is named by various researchers which include Cotter (1933), Middlemiss (1896) and Gee (1945) as "Kioto Limestone", Gee (1945) as "Baroach Limestone", Latif (1970) as "Sikhar Limestone", and Shah (2009) as "Samana Suk Formation". The rock unit mainly consists of thin to thick-bedded oolitic limestone, marls, dolostone, and interbedded clays (Ali et al. 2013; Wadood et al. 2020). The Samana Suk Formation has lower confirmable contact with Shinawari Formation and upper unconformable contact with the Cretaceous Chichali Formation (Shah, 2009). In the present palynostratigraphic study, the age diagnostic flora within the clays of the Samana Suk Formation includes the Perinopollenites elatoides, Tasmanites suevicus, and Leptolepidites verrucatus that confirm a late Bathonian-Tithonian age of the Samana Suk Formation (Fig. 2).

\section{Hydrocarbon reservoir assessment}

\section{Petrographic analysis}

Various petrographic attributes including grain types, matrix, cement, and porosity types are recorded in detail. The semi-quantitative data are calculated by visual estimation. The data are subsequently used to evaluate the reservoir potential of the rock units. The petrographic studies of the Datta Formation elucidated the abundance of quartz as a framework component (Fig. 3a-d; Table 1). It also contains a minor amount of other mineral grains, i.e., feldspars and heavy minerals. The grains are medium to coarse-grained and are sub-rounded. The rock unit is texturally immature; however, the abundance of quartz grains make the rock unit mature mineralogically. The irregular contact between the quartz grains provided conduits for fluid flow (intergranular porosity). However, at places, these pore spaces are filled by ferruginous clays, minor matrix, and silica-rich cement. The dolomite cement is seen between the quartz grains. The rock unit constitutes abundant dissolution (moldic) and fracture porosity.

The petrographic analysis of the Shinawari Formation revealed the dominance of matrix with grains showing mud-wacke-grainstone texture (Fig. 3e-h; Table 2). However, among these textures, the mud-wackestone textures are dominantly observed. The grains are embedded in the micritic matrix and minor cement. At places, intergranular, intragranular, and fracture porosities are observed. The clastic rock unit shows the irregular occurrence of highly 
Fig. 2 Pollen and spores of Datta Formation: a-c Classopolis turbatus $\mathbf{d}-\mathbf{f}$ Callialasporites dampieri, Pollen and spores of Shinawari Formation: $\mathbf{g}-\mathbf{j}$ Callialasporites trilobatus, Pollen and spores of Samana Suk Formation: k Perinopollenites elatoides $\mathbf{l}$ Leptolepidites verrucatus (Note: while scale bar is $300 \mathrm{um})$

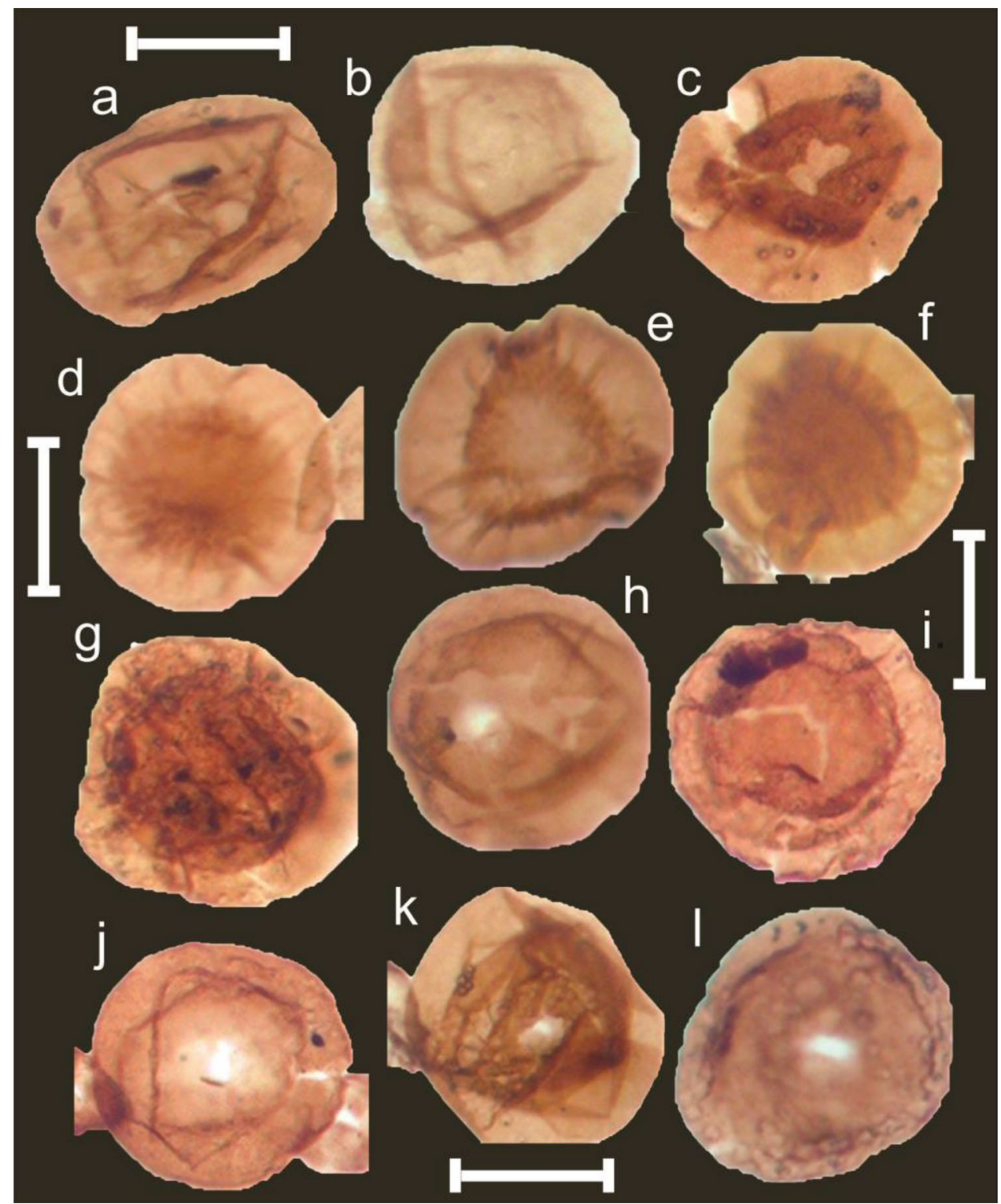

compacted quartz grains. However, the clastic unit still shows signs of dolomitization and intergranular porosity.

The microscopic analysis of the carbonates of Samana Suk Formation show both skeletal and non-skeletal grains (Fig. 3i-l; Table 3). The limestone mostly shows grainstone texture with alternate minor mud-wackestone textures. The grains are mostly bioclasts, ooids, pellets, and peloids. However, unfilled fractures and abundance of dissolution cavities are observed in the mud-wacke texture. Similar activities are also noticed in the grain dominated fabric with minor intercrystalline and intracrystalline porosity.

\section{Scanning electron microscopic analysis}

The nano-porosity evolution and differentiation of the Jurassic rocks are attained by using the SEM analysis. The Datta
Formation revealed the presence of abundant quartz grains associated with clays and iron oxides (hematite) (Fig. 4a-c). The randomly distributed clay minerals are interpreted as illite and smectite. The intense dissolution activities are also observed which have resulted in the creation of micro-macro-pores. The SEM analysis confirmed the presence of intergranular porosity.

Likewise, the Shinawari Formation also constitutes the dissolution, intergranular, and intragranular porosities (Fig. 4d-f). The fine-grained calcite rich matrix shows intense dissolution activities throughout the rock unit.

The SEM analysis of the Samana Suk Formation divulges the presence of intergranular, intragranular, and dissolution porosities (Fig. 4g-i). At places, randomly distributed minor dolomite rhombs are observed in the carbonates of Samana Suk Formation. 


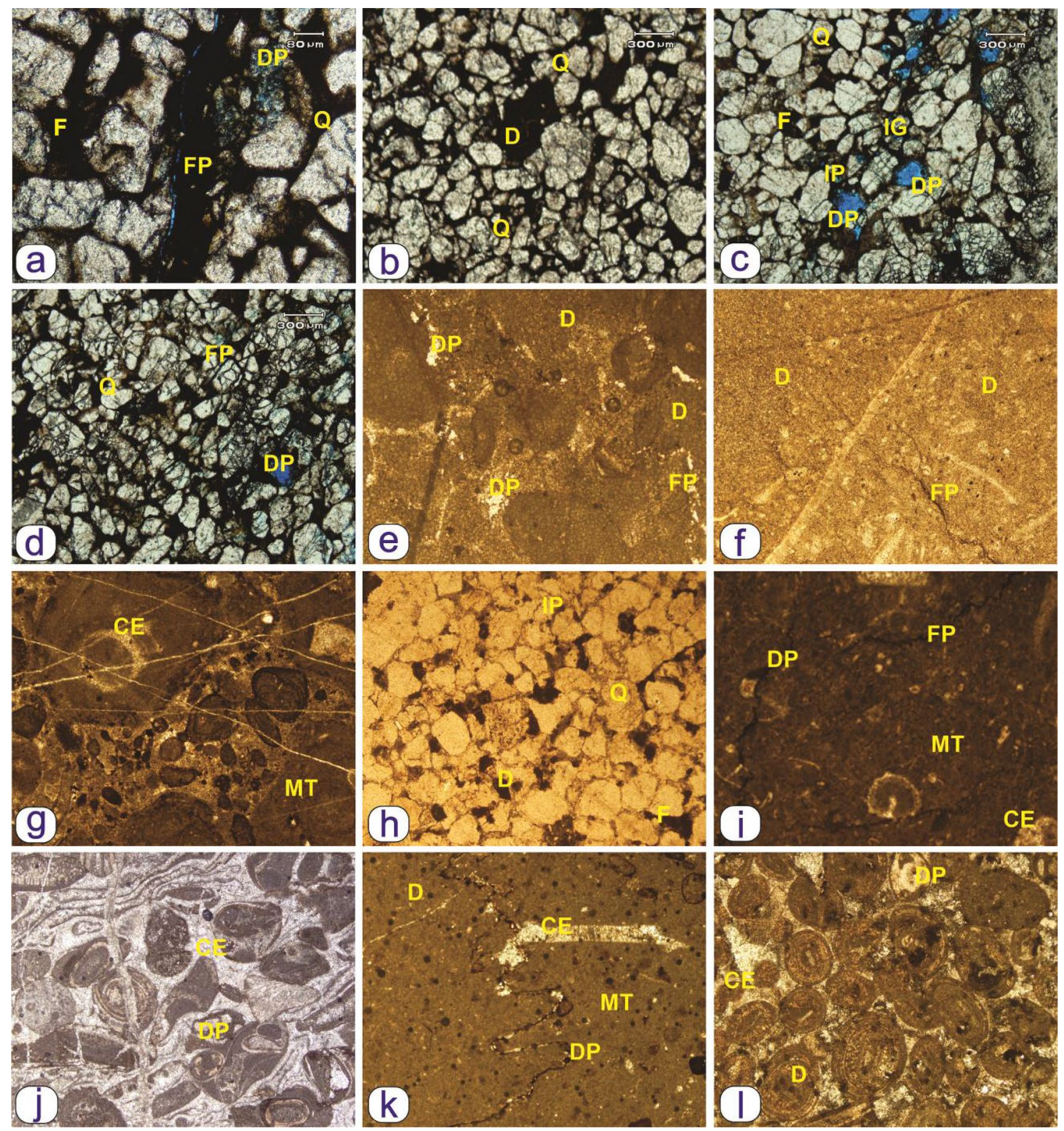

Fig. 3 Photomicrographs of the Jurassic Datta a-d, Shinawari e-h and Samana Suk i-l formations, Kala Chitta Range, Northwest Pakistan. Ferrugenious clays (F), Fracture porosity (FP), Dissolution porosity (DP), Quartz (Q), Dolomite (D), Intergranular porosity (IP), Intragranular porosity (IG), Cement (CE), and Matrix (MT)

\section{X-ray diffraction analysis}

The XRD analysis of the Datta Formation shows the presence of abundant quartz followed by calcite and minor kaolinite (clay) components (Fig. 5a). Similarly, the Shinawari Formation is comprised of calcite and minor quartz minerals (Fig. 5b). The carbonates of the Samana Suk Formation constitute calcite, dolomites, and albite minerals (Fig. 5c).

\section{Plug porosity and permeability analyses}

The visually estimated porosity and permeability of the Jurassic strata are further supplemented by the quantitative plug porosity and permeability analyses. According to the porosity and permeability data, the Datta Formation has porosity values range from 12.1 to $23.6 \%$, while the permeability ranges from 2.1 to $6.1 \mathrm{Ka} \mathrm{mD}$ (Table 4). The Shinawari Formation shows porosity range from 0.8 to 


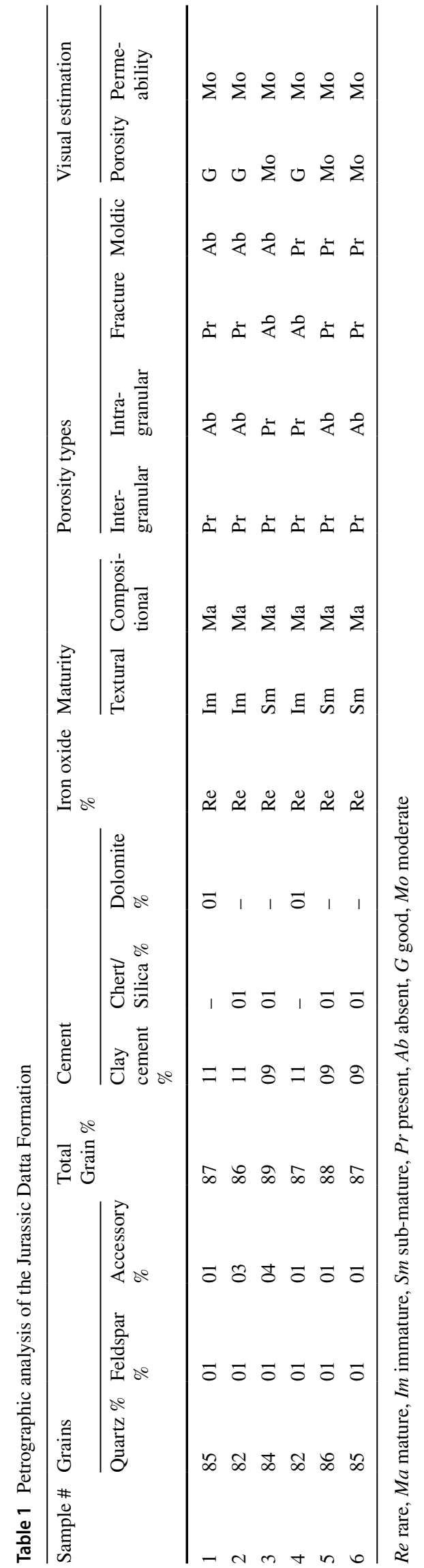

$2.9 \%$, while permeability ranges from 0.01 to $0.09 \mathrm{Ka} \mathrm{mD}$ (Table 4). Likewise, the Samana Suk Formation provides porosity values from 0.9 to $4.3 \%$ and permeability from 0.04 to $0.5 \mathrm{Ka} \mathrm{mD}$ (Table 4). The macro- and micro-porosity distribution using conventional thin-section petrography (macro) and scanning electron microscopy (micro) of the Jurassic Datta, Shinawari, and Samana Suk formations are also calculated (Table 5). The relationship between porosity and permeability is calculated by cross-plotting the porosity and permeability values (Fig. 6). The Datta and Shinawari formations show a covariant trend between porosity and permeability (Fig. 6). However, the lower part of the Samana Suk Formation does not show a direct relationship between porosity and permeability (Fig. 6).

\section{Discussion}

\section{Reservoir potential of Datta Formation}

The pore spaces in the sandstone of Datta Formation are partially filled by dolomites and iron-rich clay matrix (calcite and kaolinite minerals). The dolomite has a significant impact on enhancing the reservoir quality of the rock unit (see, e.g., Wadood et al. 2019). However, the clay minerals can significantly hinder the fluid flow (Aksu et al. 2015). The genesis of dolomite follows certain criteria including (1) thermodynamic (2) kinetic and (3) hydrologic (Machel 2004). In the case of Datta Formation, the supply of magnesium may be linked with the seawater diffusion. The intense dissolution within the Datta Formation may have added to the reservoir potential of the rock unit. The microscopic study demonstrates that dissolution activities are higher in calcite than dolomite; it shows that the rate of precipitation of dolomites was far lesser than the dissolution activities (Machel 2004). The presence of fibrous-platy hematite in the pore spaces might have encumbered the overall porosity of the Datta Formation. The hematite in the rock unit may have been formed by the alteration of goethite (Walker et al. 1981; Catling and Moore 2003). The goethite is usually formed at intermediate temperatures (alkaline conditions), while the hematite is dominant at high temperatures under the neutral pH (Schwertmann and Murad 1983), which indicates that the goethite form prior to the hematite during the course of diagenesis. The dominant higher values of quantitative plug porosity/permeability, the coarse grain sizes, and high secondary porosity hint toward excellent reservoir potential of the Datta Formation.

\section{Reservoir potential of Shinawari Formation}

The intergranular pores within the depositional fabric of the Shinawari Formation are filled by micrite, ferruginous

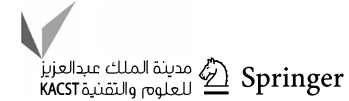


Table 2 Petrographic analysis of the Jurassic Shinawari Formation

\begin{tabular}{|c|c|c|c|c|c|c|c|c|c|}
\hline \multirow[t]{2}{*}{ Sample \# } & \multirow[t]{2}{*}{ Grain \% } & \multirow[t]{2}{*}{ Matrix \% } & \multirow[t]{2}{*}{ Cement $\%$} & \multicolumn{4}{|l|}{ Porosity types } & \multicolumn{2}{|c|}{ Visual estimation } \\
\hline & & & & Intergranular & Intragranular & Fracture & Dissolution & Porosity & Permeability \\
\hline 1 & 75 & 10 & 15 & $\operatorname{Pr}$ & $\mathrm{Ab}$ & $\mathrm{Ab}$ & $\operatorname{Pr}$ & $\mathrm{L}$ & $\mathrm{L}$ \\
\hline 2 & 09 & 80 & 11 & $\mathrm{Ab}$ & $\mathrm{Ab}$ & $\operatorname{Pr}$ & $\operatorname{Pr}$ & $\mathrm{L}$ & $\mathrm{L}$ \\
\hline 3 & 78 & 12 & 10 & $\operatorname{Pr}$ & $\mathrm{Ab}$ & $\mathrm{Ab}$ & $\operatorname{Pr}$ & Mo & $\mathrm{L}$ \\
\hline 4 & 25 & 70 & 05 & $\operatorname{Pr}$ & $\operatorname{Pr}$ & $\operatorname{Pr}$ & $\operatorname{Pr}$ & G & $\mathrm{L}$ \\
\hline 5 & 08 & 87 & 05 & $\mathrm{Ab}$ & $\mathrm{Ab}$ & $\mathrm{Ab}$ & $\operatorname{Pr}$ & $\mathrm{L}$ & $\mathrm{L}$ \\
\hline 6 & 81 & 5 & 14 & $\operatorname{Pr}$ & $\operatorname{Pr}$ & $\operatorname{Pr}$ & $\operatorname{Pr}$ & $\mathrm{G}$ & $\mathrm{L}$ \\
\hline
\end{tabular}

$\operatorname{Pr}$ present, $A b$ absent, $L$ low, $G$ good, $M o$ moderate

Table 3 Petrographic analysis of the Jurassic Samana Suk Formation

\begin{tabular}{|c|c|c|c|c|c|c|c|c|c|}
\hline \multirow[t]{2}{*}{ Sample \# } & \multirow[t]{2}{*}{ Grain\% } & \multirow[t]{2}{*}{ Matrix\% } & \multirow[t]{2}{*}{ Cement $\%$} & \multicolumn{4}{|l|}{ Porosity types } & \multicolumn{2}{|c|}{ Visual estimation } \\
\hline & & & & Intergranular & Intragranular & Fracture & Dissolution & Porosity & Permeability \\
\hline 1 & 70 & 10 & 20 & $\mathrm{Ab}$ & $\mathrm{Ab}$ & $\operatorname{Pr}$ & $\operatorname{Pr}$ & Mo & $\mathrm{L}$ \\
\hline 2 & 80 & 10 & 10 & $\mathrm{Ab}$ & $\mathrm{Ab}$ & $\mathrm{Ab}$ & $\operatorname{Pr}$ & $\mathrm{L}$ & $\mathrm{L}$ \\
\hline 3 & 10 & 85 & 05 & $\operatorname{Pr}$ & $\operatorname{Pr}$ & $\operatorname{Pr}$ & $\operatorname{Pr}$ & G & $\mathrm{L}$ \\
\hline 4 & 20 & 65 & 15 & $\operatorname{Pr}$ & $\operatorname{Pr}$ & $\operatorname{Pr}$ & $\operatorname{Pr}$ & G & $\mathrm{L}$ \\
\hline 5 & 82 & 08 & 10 & $\mathrm{Ab}$ & $\mathrm{Ab}$ & $\mathrm{Ab}$ & $\operatorname{Pr}$ & $\mathrm{L}$ & $\mathrm{L}$ \\
\hline 6 & 25 & 65 & 10 & $\mathrm{Ab}$ & $\mathrm{Ab}$ & $\operatorname{Pr}$ & $\operatorname{Pr}$ & Mo & $\mathrm{L}$ \\
\hline
\end{tabular}

Pr present, $A b$ absent, $L$ low, $G$ good, $M o$ moderate

clays, and dolomites. The calcite has filled the microscopic fractures. The dolomitization is closely linked with ferruginous-clay solutions released during the late diagenetic process which might have contributed to the overall secondary porosity (see, e.g., Mattes and Mountjoy 1980; Gregg 1985; Gregg and Shelton 1989; Machel and Anderson 1989; Keller et al. 2000). The bulk geochemical analysis shows the presence of calcite with minor quartz in the rock unit. However, dissolution and intergranular porosities are observed during SEM analyses which may provide a sufficient path for the flow of hydrocarbons. The dolomitization, fracturing, and dissolution have appended to the enhancement of the reservoir potential. The Shinawari Formation has experienced deep burial diagenetic processes. Such diagenesis enhances the porosity (by dissolution/by enhancing pre-existing pores) and also reduces the porosity (by compaction and cementation). Such diagenetic modifications can be related temporally and spatially to the burial depth temperature-hydrologic history of sedimentary basins and their hydrocarbon maturation migration-destruction history (i.e., Burruss et al. 1985; Crossey et al. 1986; Edman and Surdam 1986; Druckman and Moore 1985; Hutcheon et al. 1989; Surdam et al. 1984, 1989; Mazzullo and Harris 1989). Based on detail petrographic, SEM, plug porosity/permeability, and XRD observations, the Shinawari Formation is categorized as a moderate reservoir in the study area.

\section{Reservoir potential of Samana Suk Formation}

The Samana Suk Formation is dominantly comprised of limestone with alternate marls and sandstone. The petrographic studies revealed the presence of various types of matrix and cement including coarse-fine dolomites, micrite, and calcite. The calcite cementation most probably has occurred at the shallow diagenetic phase, as it is dependent on pressure, temperature, salinity, the composition of pore water, fabric, and mineralogy (James and Choquette 1983). The calcite cement may produce by the dissolution of aragonite and high-magnesium calcite and convert these into low magnesium calcite (Boggs and Boggs 2009). The diagenetic processes in the Samana Suk Formation have greatly affected the porosity of the rock unit. The late diagenetic phase has released ferruginous solutions forcing the dolomite formation. The stylolites (filled with siderite) and neomorphic calcite are developed as a result of deep burial. The presence of calcite filled veins and dolomites suggest the pronounced effects of the telogenetic phase. Although the diagenesis has destroyed much of the primary porosity, however, a late deep diagenetic phase has greatly enhanced the secondary porosity. Thus, the dissolution and inter-intragranular porosity rank the Samana Suk Formation as a potential hydrocarbon reservoir. 

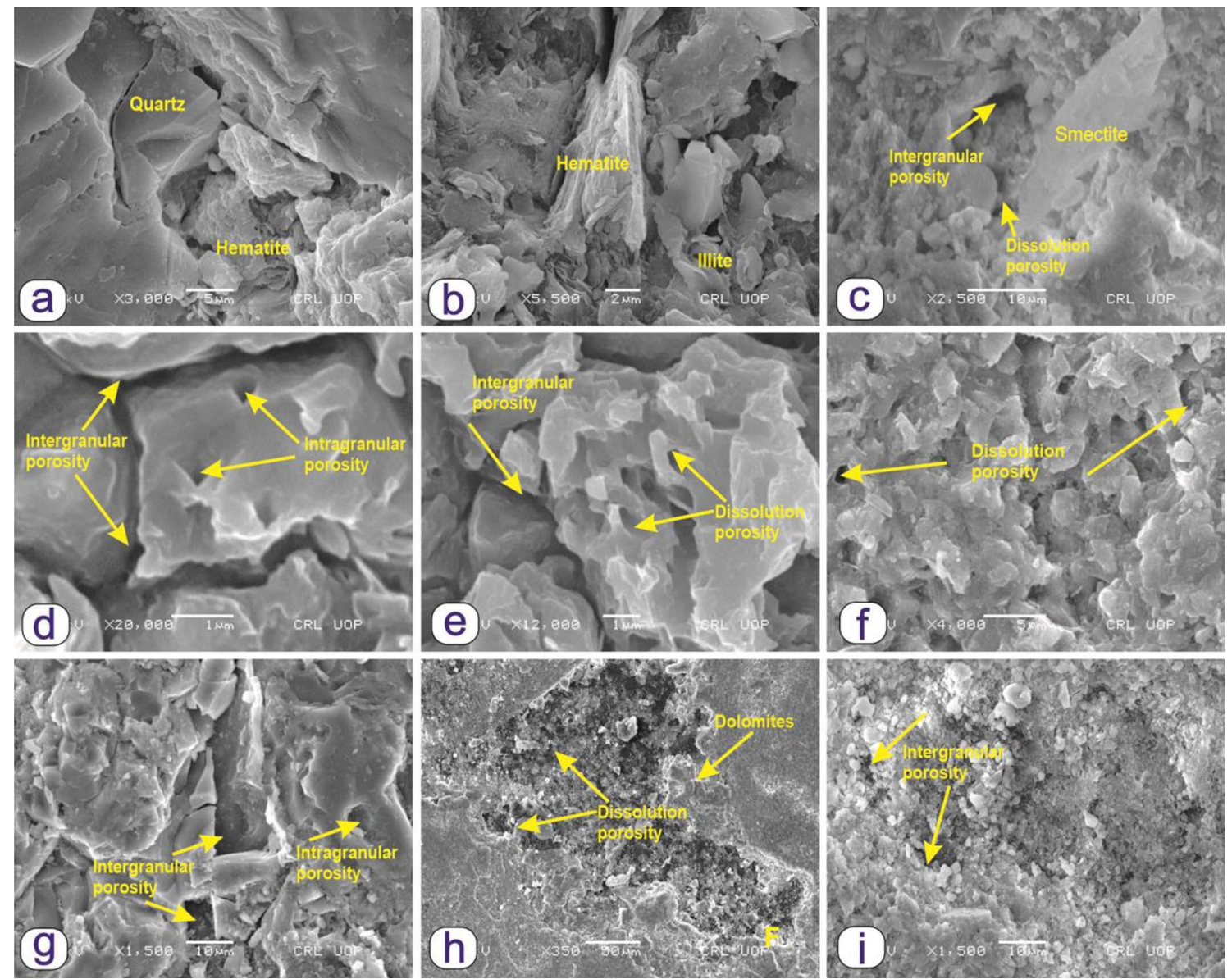

Fig. 4 Scanning electron microscopic images of the Datta $\mathbf{a}-\mathbf{c}$, Shinawari $\mathbf{d}-\mathbf{f}$, and Samana Suk $\mathbf{g}-\mathbf{i}$ formations, Kala Chitta Range, Northwest Pakistan

\section{Conclusions}

The Jurassic succession (Datta, Shinawari, and Samana Suk formations) are well exposed in the Kala Chitta Range. Based on the palynostratigraphic investigations, the Datta Formation was assigned Toarcian-Bajocian age, while the Shinawri Formation was deposited in the Bajocian-middle Bathonian age. Similarly, the Samana Suk Formation shows late Bathonian-Tithonian time of deposition. The integrated results of petrography, plug porosity/ permeability, XRD, and SEM confirm the excellent reservoir potential of the Datta Formation. The dominance of micrite, ferruginous clays, and dolomite hint toward poor reservoir potential of the Shinawari Formation, however, the enhancement of inter-intragranular pores and matrix may have enhanced the reservoir potential of the unit. The same conclusion is supported by plug porosity/permeability values. The dominance of cement, micrite, ferruginous clays superimposed by burial compaction may have occluded the primary porosity within the Samana Suk Formation. However, the diagenetic dissolution and dolomitization have induced significant porosity, thus making the Samana Suk Formation as a promising reservoir. 
a Datta Formation

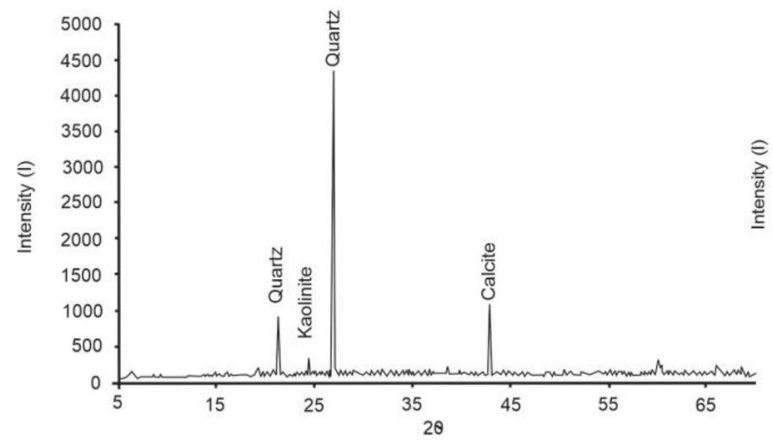

b Shinawari Formation

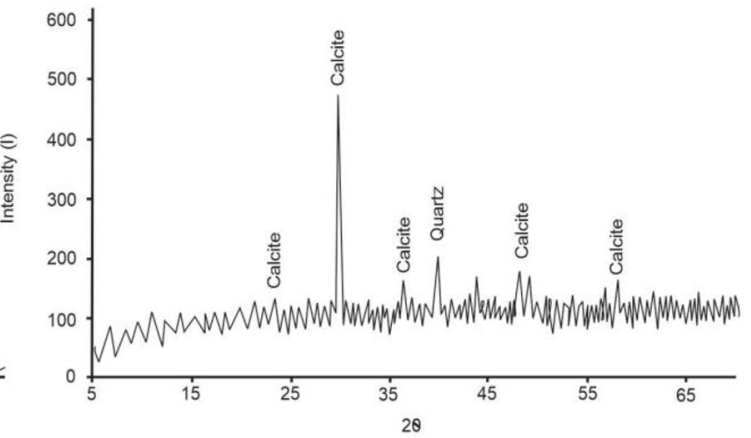

c Samana Suk Formation

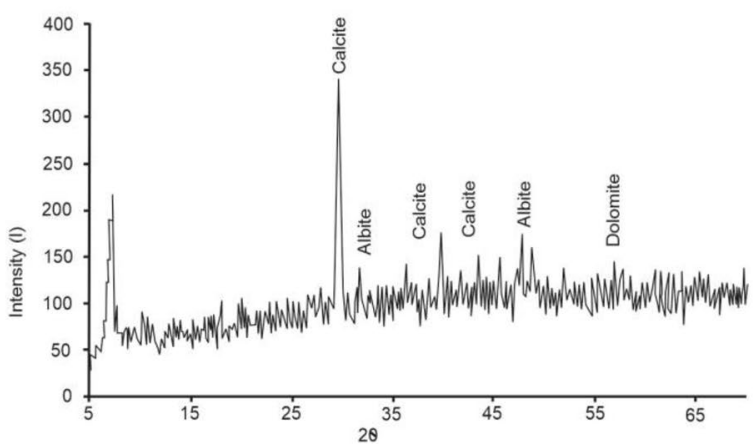

Fig. 5 XRD analysis of the selected samples (average) from Datta (a), Shinawari (b), and Samana Suk (c) formations, Kala Chitta Range, Northwest Pakistan

Table 4 Quantitative plug porosity and permeability analyses of the Jurassic Datta, Shinawari, and Samana Suk formations

\begin{tabular}{|c|c|c|c|c|c|c|c|c|}
\hline \multicolumn{3}{|c|}{ Datta formation } & \multicolumn{3}{|c|}{ Shinawari Formation } & \multicolumn{3}{|c|}{ Samana Suk Formation } \\
\hline Sample \# & Porosity (\%) & $\begin{array}{l}\text { Permeability } \\
(\mathrm{Ka} \mathrm{mD})\end{array}$ & Sample \# & Porosity $(\%)$ & $\begin{array}{l}\text { Permeability } \\
(\mathrm{Ka} \mathrm{mD})\end{array}$ & Sample \# & Porosity (\%) & $\begin{array}{l}\text { Perme- } \\
\text { ability (Ka } \\
\mathrm{mD})\end{array}$ \\
\hline 1 & 17.2 & 5.1 & 1 & 1.6 & 0.08 & 1 & 4.34 & 0.04 \\
\hline 2 & 12.1 & 3.3 & 2 & 0.9 & 0.09 & 2 & 3.45 & 0.40 \\
\hline 3 & 20.1 & 6.1 & 3 & 0.8 & 0.01 & 3 & 2.24 & 0.30 \\
\hline 4 & 16.2 & 4.2 & 4 & 2.9 & 0.04 & 4 & 1.98 & 0.50 \\
\hline 5 & 15.1 & 2.1 & 5 & 2.1 & 0.01 & 5 & 0.90 & 0.20 \\
\hline 6 & 23.6 & 5.9 & 6 & 1.8 & 0.01 & 6 & 2.99 & 0.40 \\
\hline
\end{tabular}


Table 5 Macro- and microporosity distribution using conventional thin-section petrography (macro) and scanning electron microscopy (micro) of the Jurassic Datta, Shinawari, and Samana Suk formations

\begin{tabular}{|c|c|c|c|c|c|c|c|}
\hline \multirow[t]{2}{*}{ Serial \# } & \multirow[t]{2}{*}{ Porosity types } & \multicolumn{2}{|c|}{ Datta Formation } & \multicolumn{2}{|c|}{ Shinawari Formation } & \multicolumn{2}{|c|}{$\begin{array}{l}\text { Samana Suk For- } \\
\text { mation }\end{array}$} \\
\hline & & Macro & Micro & Macro & Micro & Macro & Micro \\
\hline 1 & Fracture & $640 * 40$ & - & $600 * 80$ & - & $500 * 70$ & - \\
\hline 2 & Dissolution & $250 * 150$ & $5 * 2$ & $150 * 150$ & $2 * 1.5$ & $100 * 50$ & $25 * 20$ \\
\hline 3 & Intergranular & $75 * 50$ & $8 * 3$ & $80 * 30$ & $0.5 * 3$ & - & $7 * 10$ \\
\hline 4 & Intragranular & $50 * 60$ & - & - & $0.4 * 0.5$ & - & $4 * 3$ \\
\hline
\end{tabular}

Note First value represents length, while second value shows width of the pore space. The values are taken in micron scale a Datta Formation

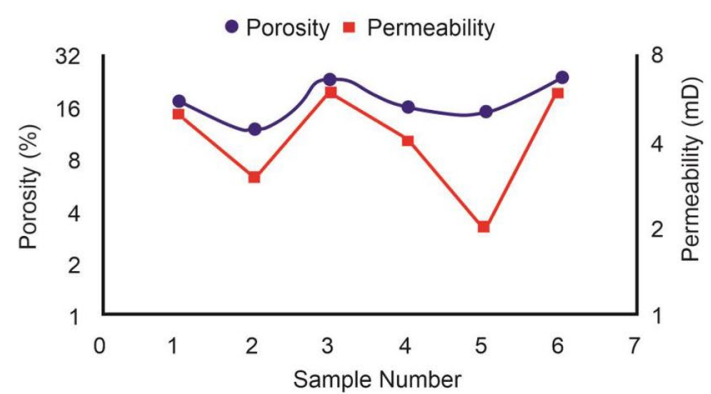

b Shinawari Formation

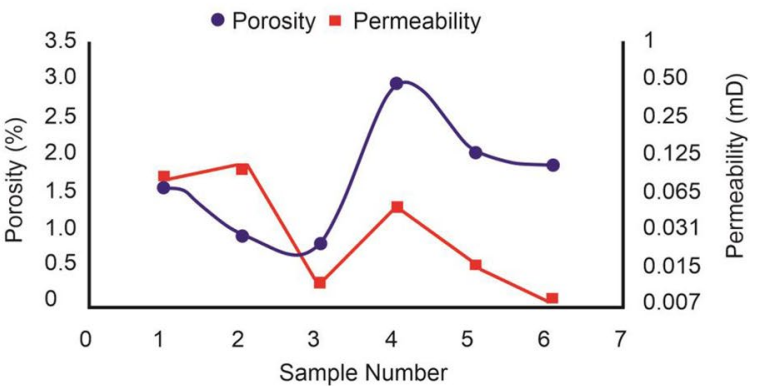

C Samana Suk Formation

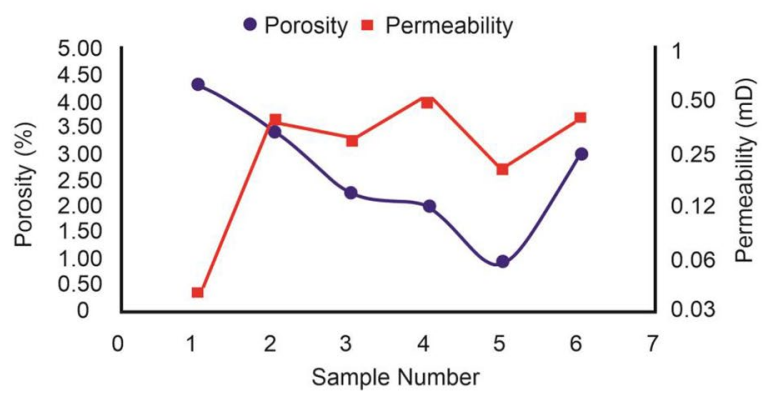

Fig. 6 Relationship between porosity and permeability of the Datta (a), Shinawari (b), and Samana Suk (c) formations, Kala Chitta Range, Northwest Pakistan

Acknowledgements The authors are thankful to Department of Geology, the University of Peshawar for providing laboratory facilities.

Funding Self-funded project.

\section{Compliance with ethical standards}

Conflict of interest The authors declare that they have no conflict of interest.

Open Access This article is licensed under a Creative Commons Attribution 4.0 International License, which permits use, sharing, adaptation, distribution and reproduction in any medium or format, as long as you give appropriate credit to the original author(s) and the source, provide a link to the Creative Commons licence, and indicate if changes were made. The images or other third party material in this article are included in the article's Creative Commons licence, unless indicated otherwise in a credit line to the material. If material is not included in the article's Creative Commons licence and your intended use is not permitted by statutory regulation or exceeds the permitted use, you will need to obtain permission directly from the copyright holder. To view a copy of this licence, visit http://creativecommons.org/licenses/by/4.0/.

\section{References}

Abbasi IA, Haneef M, Obaid S, Daud F, Qureshi AW (2012) Mesozoic deltaic system along the western margin of the Indian plate: lithofacies and depositional setting of Datta Formation. North Pak Arab J Geosci 5:471-480 
Ahmed S, Mertmann D, Manutsoglu E (1997) Jurassic shelf sedimentation and sequence stratigraphy of the Surghar Range. Pak J Nepal Geol Soc 15:15-22

Aksu I, Bazilevskaya E, Karpyn Z (2015) Swelling of clay minerals in unconsolidated porous media and its impact on permeability. GeoResJ 7:1-13

Ali SA, Clark WJ, Moore WR, Dribus JR (2010) Diagenesis and reservoir quality. Oilfield Rev 22:14-27

Ali F, Haneef M, Anjum MN, Hanif M, Khan S (2013) Microfacies analysis and sequence stratigraphic modeling of the Samana Suk Formation, Chichali Nala, Trans Indus Ranges, Punjab, Pakistan. J Himal Earth Sci 46:41-53

Ali F, Qiang J, Ahmad S, Khan S, Hanif M, Jan IU (2019) Sedimentological and geochemical analysis of the middle Jurassic Shinawari Formation, upper indus basin, Pakistan: implications for palaeoenvironmental and hydrocarbon assessment. Arab J Sci Eng 44:6465-6487

Banks C, Warburton J (1986) 'Passive-roof'duplex geometry in the frontal structures of the Kirthar and Sulaiman mountain belts, Pakistan. J Struct Geol 8:229-237

Bender FK, Raza HA (1995) Geology of Pakistan. Beträge zur regionalen Geologie der Erde, vol 25. Gebrüder Borntraeger, Berlin

Bliefnick DM, Kaldi JG (1996) Pore geometry: control on reservoir properties, walker creek field, Columbia and Lafayette counties, Arkansas. AAPG Bull 80:1027-1044

Boggs S Jr, Boggs S (2009) Petrology of sedimentary rocks. Cambridge University Press, Cambridge

Burruss RC, Cercone KR, Harris PM (1985) Timing of hydrocarbon migration: evidenced from fluid inclusions in calcite cements, tectonics and burial history. In: Schneidermann N, Harris PM (eds) Carbonate cements. SEPM Special Publication 26, pp 277-289

Calkins JA, Matin AA (1973) The geology and mineral resources of the Garhi Habibullah quadrangle and the Kakul area, Hazara District, Pakistan. US Geological Survey

Catling DC, Moore JM (2003) The nature of coarse-grained crystalline hematite and its implications for the early environment of Mars. Icarus 165:277-300

Cheema AH (2010) Microfacies, diagenesis and depositional environments of Samana Suk formation (middle Jurassic) Carbonates exposed in South East Hazara and Samana range. University of the Punjab, Lahore

Cotter GP (1933) The geology of the part of the Attock district west of longitude 7245 E. Mem Geol Surv India 55:63-161

Crossey LJ, Surdam RC, Lahann R (1986) Application of organic/inorganic diagenesis to porosity prediction. In: Gautier DL (ed) Role of organic matter in sediment diagenesis. SEPM Special Publication 38. Society of Economic Paleontologists and Mineralogists, Tulsa, pp 147-155

Druckman Y, Moore CH (1985) Late subsurface secondary porosity in a Jurassic grainstone reservoir, Smackover Formation, Mt. Vernon field, southern Arkansas. In: Roehl PO, Choquette PW (eds) Carbonate petroleum reservoirs, Casebooks in Earth Sciences. Springer, New York, pp 369-383

Edman JD, Surdam RC (1986) Organic-inorganic interactions as a mechanism for porosity enhancement in the Upper Cretaceous Ericson Sandstone. Green River Basin, Wyoming

EIA U (2013) United States Energy Information Administration. 2013. Annual Energy Outlook

Evans RC (1987) An investigation into the influence of common sedimentary structures and diagenesis on permeability heterogeneity and anisotropy in selected sands and sandstones. Soc Pet Eng paper 17130

Fatmi AN (1973) Lithostratigraphic units of the Kohat-Potwar province, Indus basin. Geological Survey of Pakistan, Balochistan
Fatmi A, Hyderi I, Anwar M (1990) Occurrence of the lower Jurassic ammonoid genus bouleiceras from the Surghar range with a revised nomenclature of the mesozoic rocks of the salt range and trans indus ranges (upper indus basin). Geol Bull Punjab Univ 25:38-46

Foscolos A (1984) Diagenesis 7. Catagenesis of argillaceous sedimentary rocks. Geosci Canada 11:67-75

Gee E (1945) The age of the Saline Series of the Punjab and of Kohat. Proc Natl Acad Sci India 14:269-310

Gregg JM (1985) Regional epigenetic dolomitization in the Bonneterre Dolomite (Cambrian), southeastern Missouri. Geology 13:503-506

Gregg JM, Shelton KL (1989) Minor-and trace-element distributions in the Bonneterre Dolomite (Cambrian), southeast Missouri: evidence for possible multiple-basin fluid sources and pathways during lead-zinc mineralization. Geol Soc Am Bull 101:221-230

Hallam A, Maynard J (1987) The iron ores and associated sediments of the Chichali formation (Oxfordian to Valanginian) of the TransIndus Salt Range. Pak J Geol Soc 144:107-114

Hutcheon I, Abercrombie HJ, Putnam P, Gardner R, Krouse HR (1989) Diagenesis and sedimentology of the Clearwater formation at Tucker Lake. Bull Can Pet Geol 37:83-97

Iqbal S, Jan IU, Akhter MG, Bibi M (2015) Palaeoenvironmental and sequence stratigraphic analyses of the Jurassic Datta formation, Salt Range, Pakistan. J Earth Syst Sci 124:747-766

James NP, Choquette PW (1983) Diagenesis 5. Limestones: introduction. Geosci Canada 10:159-161

Jodry R (1972) Pore geometry of carbonate rocks (basic geologic concepts). In: Chilingar GV et al (eds) Oil and gas production from carbonate rocks. Elsevier, New York, pp 408

Kadri IB (1995) Petroleum geology of Pakistan. Pak Pet Ltd, Karachi

Kazmi AH, Rana RA (1982) Tectonic map of Pakistan 1: 2000 000: Map showing structural features and tectonic stages in Pakistan. Geological Survey of Pakistan

Keller TJ, Gregg JM, Shelton KL (2000) Fluid migration and associated diagenesis in the Greater Reelfoot rift region, Midcontinent, United States. GSA Bull 112:1680-1693

Khan N, Rehman K (2019) Petrophysical evaluation and fluid substitution modeling for reservoir depiction of Jurassic Datta Formation in the Chanda oil field, Khyber Pakhtunkhwa, northwest Pakistan. J Pet Explor Prod Technol 9:159-176

Kopaska-Merkel DC, Mann SD, Schmoker JW (1994) Controls on reservoir development in a shelf carbonate: Upper Jurassic Smackover formation of Alabama. AAPG Bull 78:938-959

Latif M (1970) Explanatory notes on the geology of southeastern Hazara to accompany the revised geological map Jahrbuch der Geologischen Bundesanstalt. Sonderband 15:5-20

Machel HG (2004) Concepts and models of dolomitization: a critical reappraisal. Geol Soc Lond Spec Publ 235:7-63

Machel HG, Anderson JH (1989) Pervasive subsurface dolomitization of the Nisku Formation in central Alberta. J Sediment Res 59:891-911

Mattes BW, Mountjoy EW (1980) Burial dolomitization of the upper devonian miette buildup. Jasper National Park, Alberta

Mazzullo S, Harris P (1989) Porosity formation in deep-burial environment: overview, with examples, from Permian Basin. Am Assoc Pet Geol Bull 73:388

Mertmann D, Ahmad S (1994) Shinawari and Samana Suk Formations of the Surghar and salt ranges, Pakistan: facies and depositional environments. Z der Deutsch Geol Gesellschaft 145:305-317

Middlemiss CS (1896) The geology of Hazara and the Black Mountain, vol 26. Geological Survey, Virginia

Moore CH, Druckman Y (1981) Burial diagenesis and porosity evolution, upper Jurassic Smackover, Arkansas and Louisiana. Aapg Bull 65:597-628

Nizami AR (2009) Microfacies analysis and diagenetic settings of the middle Jurassic Samana Suk Formation, Sheikh Budin Hill 
section, trans Indus ranges-Pakistan. Geol Bull Punjab Univ 44:69-84

Nizami AR, Shiekh RA (2009) Microfacies analysis and diagenetic settings of the Samana Suk Formation, Chichali Nala Section, Surghar Range, Trans Indus Ranges, Pakistan. Geol Bull Punjab Univ 42:37-52

Potter PE, Maynard JB, Pryor WA (2012) Sedimentology of shale: study guide and reference source. Springer, Berlin

Qureshi MKA, Butt AA, Ghazi S (2008) Shallow shelf sedimentation of the Jurassic Samana Suk Limestone, Kala Chitta Range, Lesser Himalayas, Pakistan. Geol Bull Punjab Univ 43:1-14

Schwertmann U, Murad E (1983) Effect of $\mathrm{pH}$ on the formation of goethite and hematite from ferrihydrite. Clays Clay Min 31:277-284

Selley RC, Sonnenberg SA (2014) Elements of petroleum geology. Academic Press, Cambridge

Shah SMI (2009) Stratigraphy of Pakistan. Geol Surv Pak Mem $22: 1-381$

Shah SBA, Ahmed A (2018) Hydrocarbon source rock potential of Paleocene and Jurassic deposits in the Panjpir oilfield subsurface, Punjab Platform, Pakistan. Arab J Geosci 11:607

Spirakis CS, Heyl AV (1988) Possible effects of thermal degradation of organic matter on carbonate paragenesis and fluorite precipitation in Mississippi Valley-type deposits. Geology 16:1117-1120

Surdam RC, Boese SW, Crossey LJ (1984) The chemistry of secondary porosity. In: McDonald DA, Surdam RC (eds) Clastic Diagenesis. American Association of Petroleum Geologists Memoir, vol 37, pp 127-150

Surdam RC, Crossey LJ, Hagen ES, Heasler HP (1989) Organic-inorganic interactions and sandstone diagenesis. AAPG Bull 73:1-23
Wadood B, Awais M, Khan S, Ahmad S, Ahmad L, Muslim M (2019) Diagenetic studies of the Cretaceous turbidities, Sulaiman Range, Pakistan: Implications for reservoir quality. J Himal Earth Sci 52:106-119

Wadood B, Khan S, Li H, Liu Y, Ahmad S, Jiao X (2020) Sequence stratigraphic framework of the Jurassic Samana Suk carbonate formation, North Pakistan: implications for reservoir potential. Arab J Sci Eng. https://doi.org/10.1007/s13369-020-04654-9

Walker TR, Larson EE, Hoblitt RP (1981) Nature and origin of hematite in the Moenkopi Formation (Triassic), Colorado Plateau: a contribution to the origin of magnetism in red beds. J Geophys Res Solid Earth 86:317-333

Wardlaw N, Cassan J (1978) Estimation of recovery efficiency by visual observation of pore systems in reservoir rocks. Bull Can Pet Geol 26:572-585

Wilson M, Wilson L, Patey I (2014) The influence of individual clay minerals on formation damage of reservoir sandstones: a critical review with some new insights. Clay Min 49:147-164

Yeats RS, Hussain A (1987) Timing of structural events in the Himalayan foothills of northwestern Pakistan. Geol Soc Am Bull 99:161-176

Publisher's Note Springer Nature remains neutral with regard to jurisdictional claims in published maps and institutional affiliations. 